\title{
Matrix gla protein (MGP): an overexpressed and migration-promoting mesenchymal component in glioblastoma Sonja Mertsch ${ }^{1}$, Leon J Schurgers ${ }^{2}$, Kathrin Weber ${ }^{1}$, Werner Paulus ${ }^{1}$ and Volker Senner*1
}

\author{
Address: ${ }^{1}$ Institute of Neuropathology, University Hospital Münster, Münster, Germany and ${ }^{2}$ VitaK Inc. and Cardiovascular Research Institute \\ CARIM, Maastricht, the Netherlands \\ Email: Sonja Mertsch - sonja.mertsch@ukmuenster.de; Leon J Schurgers - L.Schurgers@BIOCH.unimaas.nl; \\ Kathrin Weber - kathrin.weber@ukmuenster.de; Werner Paulus - werner.paulus@uni-muenster.de; Volker Senner* - senner@uni-muenster.de \\ * Corresponding author
}

Published: 27 August 2009

BMC Cancer 2009, 9:302 doi:10.1 186/147/-2407-9-302
Received: 16 December 2008

Accepted: 27 August 2009

This article is available from: http://www.biomedcentral.com/I47I-2407/9/302

(c) 2009 Mertsch et al; licensee BioMed Central Ltd.

This is an Open Access article distributed under the terms of the Creative Commons Attribution License (http://creativecommons.org/licenses/by/2.0), which permits unrestricted use, distribution, and reproduction in any medium, provided the original work is properly cited.

\begin{abstract}
Background: Recent studies have demonstrated that a molecular subtype of glioblastoma is characterized by overexpression of extracellular matrix (ECM)/mesenchymal components and shorter survival. Specifically, gene expression profiling studies revealed that matrix gla protein (MGP), whose function has traditionally been linked to inhibition of calcification of arteries and cartilage, is overexpressed in glioblastomas and associated with worse outcome.
\end{abstract}

Methods: In order to analyze the role of MGP in glioblastomas, we performed expression, migration and proliferation studies.

Results: Real-time PCR and ELISA assays confirmed overexpression of MGP in glioblastoma biopsy specimens and cell lines at mRNA and protein levels as compared to normal brain tissue. Immunohistochemistry verified positivity of glial tumor cells for MGP. RNAi-mediated knockdown of MGP in three glioma cell lines (U343MG, U373MG, H4) led to marked reduction of migration, as demonstrated by wound healing and transwell assays, while no effect on proliferation was seen.

Conclusion: Our data suggest that upregulation of MGP (and possibly other ECM-related components as well) results in unfavorable prognosis via increased migration.

\section{Background}

Glioblastomas, which represent astrocytic gliomas of grade IV, are the most common and most malignant intrinsic brain tumors [1]. Despite considerable improvements in surgery, radiation therapy and chemotherapy, the prognosis of patients with glioblastoma remains dismal with median survival of about 15 months. A major reason for this unfavorable outcome is extensive, diffuse invasion of glial tumor cells into surrounding brain tissue, which precludes complete surgical resection and leads to rapid recurrence $[2,3]$. From the biological point of view, glioma invasion is based on interactions of tumor cells with other neoplastic or non-neoplastic cells and with the cerebral extracellular matrix (ECM).

It has been known for decades that glioblastoma cells in situ are able to produce and deposit large amounts of interstitial ECMs such as collagens, fibronectins and laminins, a process that may eventually result in gliosarcomas [4]. Furthermore, once taken into cell culture glioblast- 
oma cells usually produce increased amounts of ECM components, a process which has been designated mesenchymal drift $[5,6]$. More recent whole genome gene expression analyses have identified a subset of glioblastomas that overexpress transcripts of ECM components, corresponding to a mesenchymal gene expression profile and being associated with worse prognosis [7-9].

Matrix gla protein (MGP) is one of the mesenchymal genes overexpressed in glioblastoma samples [9] as well as in recurrent gliomas undergoing malignant progression [10]. Interestingly, MGP expression in astrocytic tumors appears to be related to grade of malignancy (http:// www.ncbi.nlm.nih.gov/geo/, Geo database accession numbers GDS1813 and GDS1962). In addition, in silico analyses using the REMBRANDT database (http://rem brandt.nci.nih.gov, accessed $10^{\text {th }}$ march 2009) revealed more than two-fold upregulation of MGP in glioblastomas as compared to non-neoplastic brain tissue, and a correlation ( $\mathrm{p}=0.0011$ ) between MGP overexpression and worse survival in glioblastomas, suggesting that MGP overexpression is prognostically relevant.

MGP was originally isolated from bone tissue and is also expressed in kidney, lung, heart, cartilage and vascular smooth muscle cells [11]. It is upregulated in a variety of tumors, including ovarian, breast, urogenital and skin cancer [12-16]. MGP is a 79-amino acid ECM protein containing post-translationally modified $\gamma$-carboxyglutamic acid residues resulting from vitamin $\mathrm{K}$ dependent carboxylation $[17,18]$. MGP is traditionally considered to be involved in the inhibition of calcification of arteries and cartilage [19], and germline mutations in MGP cause Keutel syndrome, leading to ectopic abnormal calcification and midfacial hypoplasia [20]. Because virtually nothing is known about the mechanisms linking upregulation of MGP and prognosis in gliomas and, more generally, about the function of MGP in tumors, we hypothesized that MGP promotes glioma migration and performed expression and migration analyses.

\section{Methods \\ Cell culture}

U373fast and U373slow glioma cell line subpopulations, originating from U373MG cells and selected for fast versus slow migration [21], as well as H4, U343MG, 86HG39 and U373MG glioma cell lines were cultured using standard cell culture conditions in Dulbecco's modified Eagle's minimal essential medium (DMEM) supplemented with $10 \%$ fetal calf serum (FCS), $100 \mathrm{U} / \mathrm{ml}$ penicillin and 100 $\mu \mathrm{g} / \mathrm{ml}$ streptomycin at $37^{\circ} \mathrm{C}$ in $5 \% \mathrm{CO}_{2}$.

\section{Tumor and brain samples}

Samples from brain tumor tissues were frozen in liquid nitrogen following resection. The tumors were histologi- cally diagnosed as glioblastoma according to WHO criteria [1]. Frozen section analysis verified that specimens used for RNA and protein extraction were composed of non-necrotic tumor tissue. We used 16 different glioblastoma samples $(\mathrm{n}=10$ for mRNA and $\mathrm{n}=10$ for immunohistochemical analysis, four samples were used for both analysis), including samples from 9 females and 7 males. The mean age $( \pm$ SEM) of the patients at the time of surgery was $52( \pm 0.7)$, with a range of $35-73$ years. Two out of these 16 different samples were diagnosed as secondary glioblastoma and 14 were diagnosed as primary glioblastoma. Non-neoplastic, histologically normal cerebral cortices from three adult subjects without neurological symptoms were obtained by autopsy. Approval for using tumor and brain tissues had been obtained by the local ethics commission.

\section{Immunofluorescence}

$1 \times 10^{5}$ cells seeded on glass coverslips and grown under standard conditions for $24 \mathrm{~h}$ were rinsed in phosphatebuffered saline (PBS) and fixed using 3.7\% formaldehyde in PBS. After permeabilizing with $0.1 \%$ Triton X-100 (Sigma, Deisenhofen, Germany) in PBS, cells were blocked with $0.5 \%$ BSA/PBS. The mouse monoclonal anti-MGP3-15 antibody (Axxora, Grünberg, Germany) was applied in a 1:200 dilution at $4{ }^{\circ} \mathrm{C}$ overnight. Alexa Fluor 488 conjugated anti-mouse antibody (A11029, Invitrogen, Karlsruhe, Germany, 1:200 dilution) was used as secondary antibody. Nuclei were stained with Hoechst 33258 and cells were mounted with "Fluoromount" (DAKO, Hamburg, Germany).

\section{Immunohistochemistry}

Immunohistochemical analysis of human glioblastoma tissue was done on acetone-fixed $\left(4^{\circ} \mathrm{C}, 8 \mathrm{~min}\right) 5$ - to $8-\mu \mathrm{m}$ frozen sections. The mouse monoclonal anti-MGP antibody was applied in a $1: 50$ dilution at $4^{\circ} \mathrm{C}$ overnight. For detection we used the biotinylated goat anti-mouse IgG BA2001 (dilution 1:100), a horseradish peroxidase avidin complex and AEC as substrate (secondary antibody and reagents from Vector Laboratories, Burlingame, CA). Slides were counterstained with hematoxylin.

For immunostaining on paraffin embedded tissue $[22,23]$, sections were heated in $0.2 \%(\mathrm{w} / \mathrm{v})$ citric acid at pH 6.0 in a microwave and "kept warm" for 15 min before washing with TBST (10 mM Tris- $\mathrm{HCl}, 150 \mathrm{mM} \mathrm{NaCl}$, $0.1 \%$ Tween; $\mathrm{pH} 7.6$ ) and incubation with anti-MGP3-15 ( $1 \mathrm{mg} / \mathrm{ml}$ ). The antibody was diluted 1:100 in blocking reagent (TBST/1\% BSA). Biotinylated sheep anti-mouse IgG (Amersham Biosciences, Little Chalfont, UK) was used as a secondary antibody, followed by incubation with avidin-linked alkaline phosphatase complex (DAKO); staining was performed with the alkaline phosphatase kit I (Vector Laboratories, Burlingame, CA). All 
specimens were counterstained using hematoxylin and sections were mounted using imsol-mount.

\section{ELISA Assay}

MGP protein concentrations in cell culture supernatant were quantified using a competitive MGP ELISA kit following manufacturer's instructions (Biomedica, Vienna, Austria). We used cell culture supernatant from cell lines U373fast and U373slow, as well as from the cell lines 86HG39, U373MG and U343MG cultured in DMEM without FCS for $24 \mathrm{~h}\left(1 \times 10^{6}\right.$ cells $)$. Absorption was measured at $450 \mathrm{~nm}$. All samples were analyzed in duplicate.

\section{Quantitative RT-PCR (qRT-PCR)}

Total RNA was isolated from subconfluent cultured cells using the RNeasy Plus Mini kit (Qiagen, Hilden, Germany), and from glioblastoma tissue using TRIzol (Invitrogen, Karlsruhe, Germany). Total RNA (0.5 $\mu \mathrm{g})$ was transcribed in cDNA with the High Capacity cDNA reverse Transcription Kit (Applied Biosystems, Foster City, CA) in a reaction volume of $20 \mu \mathrm{l}$. After cDNA synthesis $1 \mu \mathrm{l}$ from the reaction volume was utilized for qRT-PCR measurements. Measurements were done using TaqMan GeneExpressions Assay MGP (Hs00179899_m1, Applied Biosystems, Foster City, CA). Relative MGP mRNA levels were calculated and compared between tumor and normal tissue or between siRNA and control transfected cells, respectively. Data were normalized relative to glyceraldehyde-3-phosphate dehydrogenase (GAPDH) using primers GAPDH-for-ACC CAC TCC TCC ACC TTT GAC (bpposition 928-948), GAPDH-rev-CAT ACC AGG AAA TGA GCT TGA CAA (bp-position 1003-980) and the fluorescent labelled probe GAPDH-probe-CTG GCA TTG CCC TCA ACG ACC A (bp-position 956-977) as described previously [21]. The equation fold change $=2^{-\Delta \Delta c t}$ was applied to calculate the relative expression of MGP in siRNA transfected glioma cells versus untransfected glioma cells or tumors versus normal cortex, respectively. All measurements were done in duplicates and the experiments were repeated at least twice.

\section{RNA interference experiments}

U373fast, H4 and U343MG cells were subcultured into 24-well plates till $80 \%$ confluence. Transfections were performed using the HiPerfect transfection reagent (Qiagen) and two different small interfering RNAs (siRNAs) directed against MGP (Hs_MGP_4 HP siRNA (SI00645428); target sequence: TAG CAG CAT TAC TGA AAT ACA), Hs_MGP_8 siRNA (SI04357913); target sequence: CTC CCT ACT GCT GCT ACA CAA) and a non silencing negative control (negative control siRNA (1022076); target sequence: AAT TCT CCG AAC GTG TCA CGT) (all siRNAs purchased from Qiagen). Transfections were done according to manufacturer's instructions. Successful knockdown was verified with qRT-PCR and immunofluorescence at $24 \mathrm{~h}, 48 \mathrm{~h}$ and $72 \mathrm{~h}$ after transfection. All experiments were done independently for at least three times.

\section{Wound healing assay}

U373fast, H4 and U343MG cells were seeded at a density of $8 \times 10^{4}$ per well in a 24 -well plate. $24 \mathrm{~h}$ after siRNA transfection cells were scratched ("wounded") using the back side of a standard $100 \mu \mathrm{l}$ pipette tip. After being washed three times with PBS scratches including the flanking front lines of cells, were photographed (40-fold magnification). Cells were incubated under standard conditions and migration into the scratched area was photographed $24 \mathrm{~h}$ and $48 \mathrm{~h}$ after wounding (corresponding to $48 \mathrm{~h}$ and $72 \mathrm{~h}$ post-transfection). The edges of the wound were marked after scratching (time point $0 \mathrm{~h}$ ), cells migrating over the edges were counted and the number of cells was determined related to the total area of the scratch. Wound closing was compared between MGP knockdown cells and control transfected cells and evaluated using the analysis FIVE software (Soft Imaging System, Münster, Germany). Differences between two data points were determined by Student's t test where $\mathrm{p}<0.05$ was considered significant. Experiments were performed independently two times, evaluating $4-8$ scratches in each experiment.

\section{Transwell migration assay}

Disposable ChemoTx 96-well chemotaxis chambers (\#106-8, Neuro Probe, Cabin John, MD) were used for migration studies. Compared to classical Boyden chambers, these filters have hydrophobic masks surrounding each of the 96 filter sites. The masks eliminate the need for a top chamber, because they create surface tension, keeping the cell suspension positioned on the hydrophilic filter site located directly above the bottom wells. Each filter site is $5.7 \mathrm{~mm}$ in diameter and pores are $8 \mu \mathrm{m}$ in diameter. Wells ("lower chambers") were filled with $30 \mu \mathrm{l}$ of DMEM alone. Polycarbonate filters were positioned on microplates and secured in place with corner pins. $24 \mathrm{~h}$ after siRNA mediated knockdown $1 \times 10^{4}$ U373fast, U343MG or H4 glioma cells in $60 \mu \mathrm{l}$ DMEM were placed directly onto the filter sites ("upper chambers") and incubated for $24 \mathrm{~h}$ at $37^{\circ} \mathrm{C}$ in $5 \% \mathrm{CO}_{2}$. Non-migrating cells on the top of the filters were removed by gently wiping the filters with cotton swabs. Migrating cells on the bottom side were fixed for $10 \mathrm{~min}$ in $3.7 \%$ formaldehyde and stained with Hoechst 33258 for $3 \mathrm{~min}$. Stained cells were then captured using a BX50 microscope (Olympus, Tokyo, Japan) and cells were quantified using morphometry software (analysis FIVE, Soft Imaging System). Differences between two data points were determined by Student's ttest where $\mathrm{p}<0.05$ was considered significant. Two independent experiments were performed, each of them using 8 fold replicates. 


\section{Proliferation assay}

Cellular growth was assessed by (3-(4,5-Dimethylthiazol2-yl))-2,5-diphenyltetrazolium bromide (MTT) assay. Briefly, U373fast, H4 and U343MG cells were seeded at a density of $1 \times 10^{4}$ per well in a 96-well plate $24 \mathrm{~h}$ after siRNA transfection. For each time point, an exponential dilution series of cells was used with $1 \times 10^{5}$ cells as starting dilution. After $4 \mathrm{~h}$, the medium was replaced with 200 $\mu \mathrm{l}$ MTT solution $(0.5 \mathrm{mg} / \mathrm{ml})$ and incubated for $3 \mathrm{~h}$ at $37^{\circ} \mathrm{C}$ and $5 \% \mathrm{CO}_{2}$. MTT solution was discarded and 200 $\mu \mathrm{l}$ of isopropanol was added to dissolve the formazan crystals. Measurement was done at $570 \mathrm{~nm}$ using an ELISA reader upon $0 \mathrm{~h}, 24 \mathrm{~h}, 48 \mathrm{~h}$ and $72 \mathrm{~h}$ (corresponding to $24 \mathrm{~h}, 48 \mathrm{~h}, 72 \mathrm{~h}$ and $96 \mathrm{~h}$ after transfection). Experiments were independently performed three times, and 6-10 wells were evaluated for each experimental condition. Possible differences were determined by Student's t-test.

\section{Results}

\section{MGP is upregulated in glioblastoma tissues}

To determine MGP expression, we first performed quantitative real-time PCR experiments. The amount of MGP mRNA in glioblastoma tissues $(n=10)$ was $2.6-21.4$ fold higher compared to normal cortex tissues $(\mathrm{n}=3$, set as $100 \%, \pm 3.4 \%$ ) (Figure 1 ). To verify MGP overexpression on protein levels we performed immunohistochemistry using both frozen and paraffin sections, which showed distinct staining for MGP in tumor cells of all glioblastomas examined $(n=10)$ (Figure $2 \mathrm{a}$ and $2 \mathrm{~b})$, while cells of normal autopsy brains were negative or only faintly positive (Figure $2 \mathrm{c}$ ). An atheromatous plaque, used as positive control, exhibited staining of the media, in part being associated with lipid, which is a normal staining pattern for MGP (Figure 2d). Negative controls did not reveal any staining. MGP mRNA expression did not correlate with age, gender and location of the tumor.

\section{MGP is upregulated in glioblastoma cell lines}

The initial finding of increased MGP expression in glioblastoma tissues compared to normal cortex led us to experiments with glioblastoma cell lines with different migratory phenotype [21]. U373fast cells, characterized by an increased migratory phenotype, demonstrated 22.7fold higher MGP mRNA expression levels as compared to their slow counterparts (U373slow) and 132.8-fold overexpression compared with normal cortex (Figure 1). Two other glioblastoma cell lines, U343MG and H4, showed 11.2-fold and 5.6-fold higher MGP mRNA expression compared to normal brain tissue (Figure 1). These findings were confirmed at protein levels. ELISA analysis revealed 2.1-fold overexpression of MGP protein in U373fast cells as compared to U373slow cells. We also investigated the glioma cell lines 86HG39, U343MG and non selected U373MG and could verify MGP protein expression in the supernatants using ELISA. The cell line
86HG39 showed a concentration of $0.38 \mathrm{nmol} / \mathrm{l} \mathrm{MGP}$ protein, U343MG $0.23 \mathrm{nmol} / \mathrm{l}$ and U373MG $0.22 \mathrm{nmol} / \mathrm{l}$.

Immunofluorescence showed cytoplasmic staining with accentuation at perinuclear regions in all tested cell lines (Figure $2 \mathrm{e}-\mathrm{g}$ ). Negative controls using isotype matched irrelevant antibodies revealed no staining (Figure $2 \mathrm{~h}$ ).

\section{MGP is involved in glioma cell migration}

To examine the functional role of MGP in glioma cell migration, we first performed siRNA mediated MGP knockdown experiments with U373fast, H4 and U343MG cell lines. MGP knockdown was verified using qRT-PCR, showing residual MGP mRNA levels of $1.1 \%-12.9 \%$ at $24 \mathrm{~h}, 0.4 \%-11.7 \%$ at $48 \mathrm{~h}$, and $0.8 \%-11.6 \%$ at $72 \mathrm{~h}$ after knockdown compared to $100 \%$ MGP mRNA expression of control transfected cells $(n=8)$ (Figure 3a). Accordingly, immunofluorescence revealed reduced fluorescence intensities for both siRNAs, as illustrated for U373fast cells at $72 \mathrm{~h}$ post-transfection in Figure $3 \mathrm{~b}-\mathrm{d}$.

Wound healing assays at $24 \mathrm{~h}$ post-wounding ( $48 \mathrm{~h}$ posttransfection) and $48 \mathrm{~h}$ post-wounding (72 h post-transfection) showed decreased migration of $50.67 \% \pm 0.07 \%$ and $51.74 \% \pm 2.97 \%$ for U373fast cells $(\mathrm{p}=0.00092$ and $\mathrm{p}=0.0048$ MGP_4, $\mathrm{p}=0.00805$ and $\mathrm{p}=0.0017$ MGP_8), $52.67 \% \pm 9.09 \%$ and $43.71 \% \pm 14.16 \%$ for $\mathrm{H} 4$ cells $(\mathrm{p}=$ 0.0197 and $\mathrm{p}=0.0135 \mathrm{MGP} \_4, \mathrm{p}=0.00461$ and $\mathrm{p}=$ 0.00260 MGP_8), and 54.76\% $\pm 5.78 \%$ and $59.34 \% \pm$ $16.38 \%$ for $\mathrm{U} 343 \mathrm{MG}$ cells compared to control transfected cells $(\mathrm{p}=0.0171$ and $\mathrm{p}=0.0241 \mathrm{MGP} 44, \mathrm{p}=$ 0.00974 and $\mathrm{p}=0.00714 \mathrm{MGP}$ 8) (Figure 4).

Transwell migration assays performed with U373fast, H4 and U343MG cells also revealed inhibitory effects on cell migration following MGP knockdown. Compared to control siRNA transfected cells (set at $100 \%$ ), relative migration at $24 \mathrm{~h}$ ( $48 \mathrm{~h}$ after knockdown) following MGP knockdown using two different siRNAs was $47.7 \% \pm$ $10.3 \%$ and $44.5 \% \pm 11.5 \%$ in U373fast cells $(\mathrm{p}=9.21 \times$ $10^{-9}$ and $\left.\mathrm{p}=8.33 \times 10^{-10}\right), 36.4 \% \pm 12.1 \%$ and $37.27 \% \pm$ $11.2 \%$ in $\mathrm{H} 4$ cells $\left(\mathrm{p}=5.14 \times 10^{-10}\right.$ and $\left.\mathrm{p}=1.38 \times 10^{-9}\right)$, and $35.8 \% \pm 15.5 \%$ and $31 \% \pm 9.3 \%$ in U343MG cells $(p$ $=1.48 \times 10^{-9}$ and $\left.\mathrm{p}=3.50 \times 10^{-11}\right)$ (Figure 5).

To exclude that decreased numbers of migrating cells were the consequence of reduced proliferation, we performed proliferation assays. No difference was detected between MGP knockdown cells and control transfected cells (data not shown).

\section{Discussion}

In this study we have demonstrated that MGP expression at mRNA and protein levels is upregulated in glioblastoma tissues and cell lines, confirming previous expression 


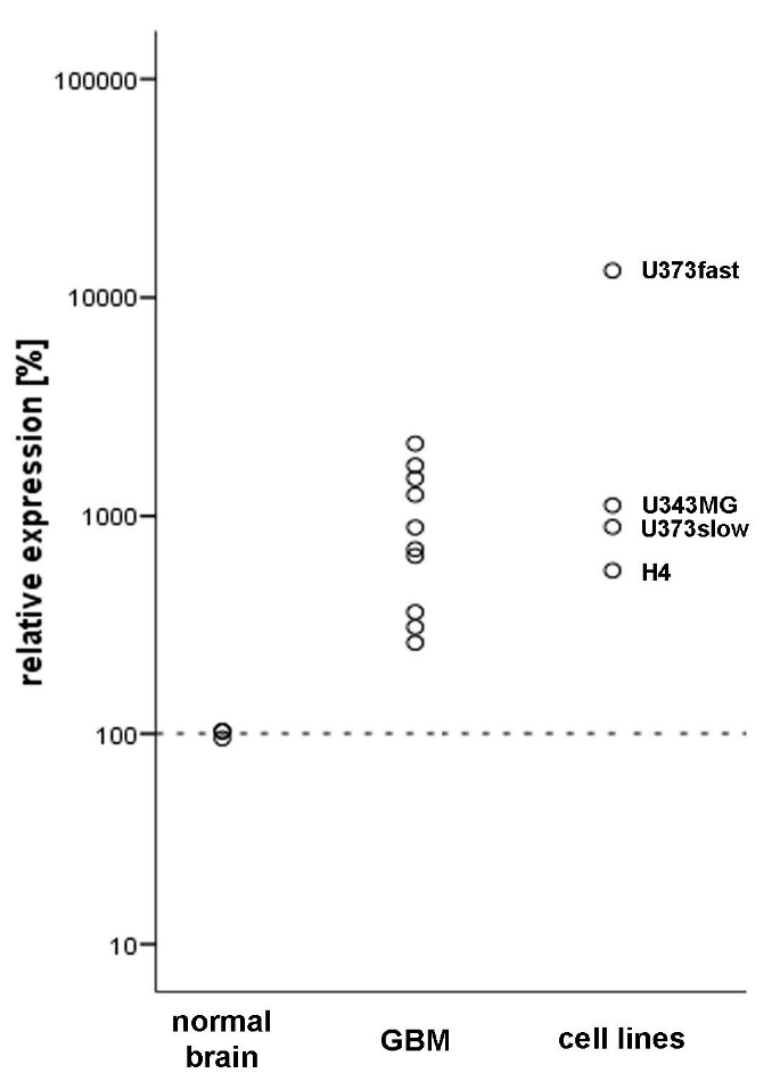

Figure I

Expression of MGP mRNA in glioblastoma tissues and cell lines. Glioblastoma (GBM) biopsy specimens $(n=$ I0) showed increased MGP mRNA levels (quantitative RT$P C R)$ as compared to normal human brain tissue $(n=3$, mean set at 100\%). Expression levels of MGP mRNA in glioma cell lines U373fast, U373slow, H4 and U343MG revealed overexpression of MGP mRNA in all cell lines compared to normal brain tissue.

profiling studies using DNA microchip analyses $[9,10]$. Based on the immunocytochemical demonstration of intracytoplasmic MGP protein in glioblastoma biopsy specimens and glioma cell lines we conclude that production by glial tumor cells rather than mesenchymal elements (e.g. abnormal blood vessels) is responsible for overexpression of this mesenchymal component in gliomas. Furthermore, human glioma cells, selected for high migration capacity (U373fast) showed elevated MGP expression compared to their less migrating counterparts (U373slow). Knockdown of MGP using siRNA in three different glioma cell lines led to decreased cell migration as demonstrated using two different migration assays, whereas proliferation remained unchanged. Collectively, these findings suggest that MGP is involved in glioblastoma cell migration in vitro.
While neural MGP expression has previously been found in rat retinal ganglion cells after induction with glia conditioned factors [24], most previous studies have focused on the role of MGP in cartilage, bone and blood vessels, because vascular smooth muscle cells and chondrocytes are the major sites of MGP expression. MGP serves as an inhibitor of cardiovascular calcification as observed in MGP null mice $[19,25]$ and arterial and valvular calcification after warfarin intake $[26,27]$. In addition, MGP enhances VEGF expression in bovine aortic endothelial cells by increasing the activity of TGF- $\beta 1$ signalling through activin-like kinase receptor 1 (ALK1) and the SMAD1/5/8 pathway [28]. The functional role of MGP in neoplasia remains unclear, but in line with our findings in gliomas, increased levels of MGP were found in ovarian, breast, urogenital and skin cancer [12-16], although decreased levels of MGP have been found in colon carcinoma [29], and loss of MGP expression in metastatic renal cell carcinoma and prostatic carcinoma compared with primary tumors has been associated with tumor progression and metastasis [15].

The mechanisms linking MGP knockdown and reduced migration of glioblastoma cells remain to be determined, but based on available evidence it is conceivable that interactions with members of the bone morphogenetic protein (BMP) family and the ECM component vitronectin are involved. BMPs belong to the transforming growth factor-beta (TGF- $\beta$ ) superfamily [30]. MGP regulates BMP4 in vascular endothelial cells, and MGP is able to bind BMP2 and promote an association between BMP2 and matrix components; interaction between MGP and BMP2 interferes with binding of BMP2 to its receptor and activation of Smad1 [28,31,32]. Furthermore, BMPs inhibit the tumorigenic potential of human brain tumorinitiating cells $[33,34]$, so that MGP-induced repression of BMP signalling may retain tumor cells in an undifferentiated state with enhanced migration potential [35]. In addition, MGP effects on glioblastoma cell migration might be mediated by binding of MGP to vitronectin [31]. Vitronectin is a multifunctional plasma and ECM protein, which serves roles in cell adhesion, complement activation, coagulation and fibrinolysis [36-39]. MGP might regulate cell migration via vitronectin receptors of the integrin family, which are known to play important roles in glioblastoma migration and invasion [40,41]. Like MGP, vitronectin expression in gliomas is known to increase with tumor grade in vivo $[40,42]$. Of note, the binding of MGP to vitronectin does not interfere with possible interactions of MGP and BMP2, because the binding regions are different [31]. Thus, the migratory promoting effect of MGP on glioblastoma cell lines might be mediated by both BMPs and vitronectin. 

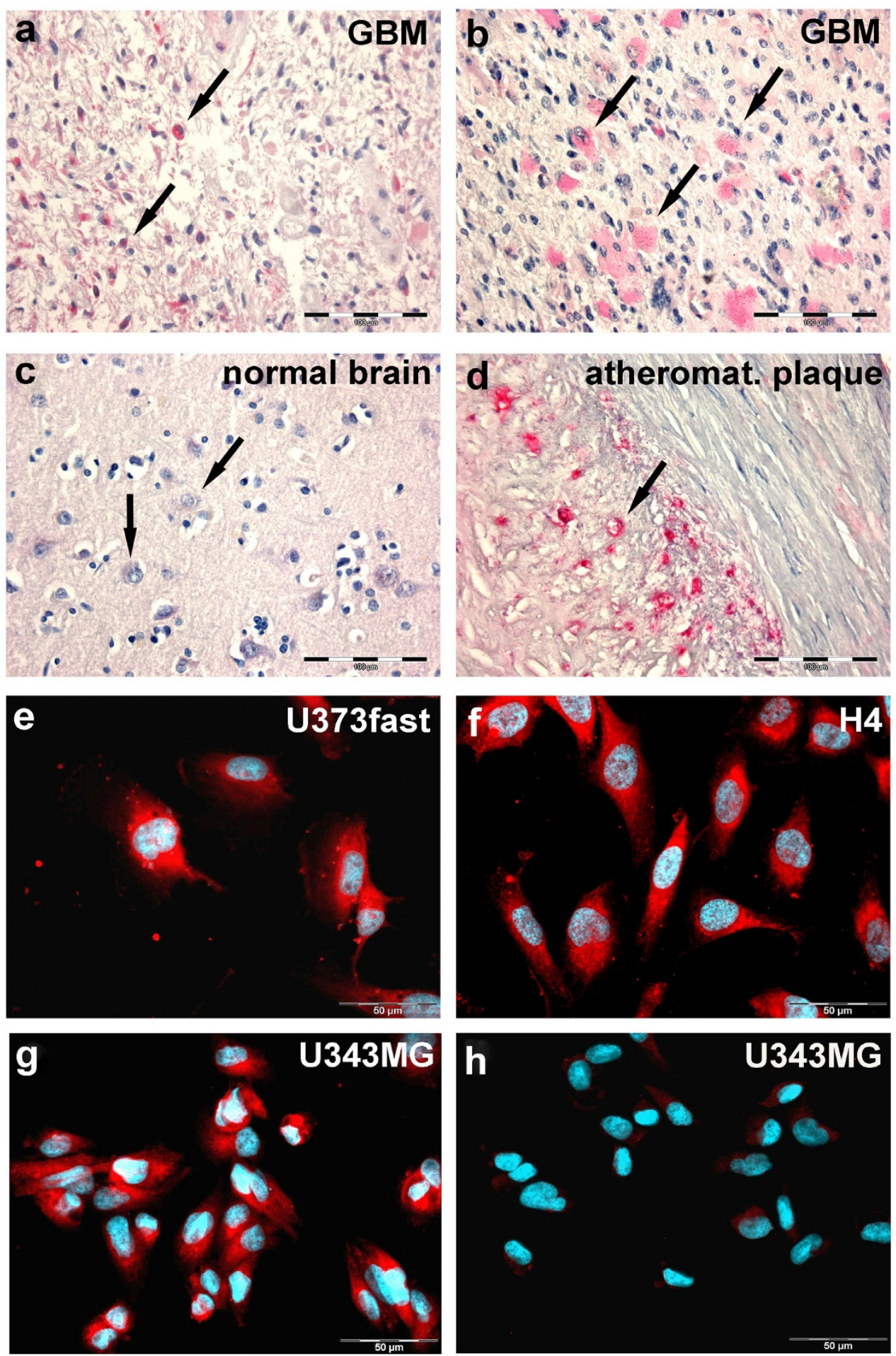

Figure 2

Cellular localization of MGP protein. Immunohistochemistry revealed positivity of tumor cells (a, b, arrow), while neurons of the normal neocortex were faintly positive (c, arrow) and glial cells were negative. An atheromatous plaque, used as positive control, showed distinct staining in the media (d, arrow). e-g: Immunofluorescence of glioblastoma cell lines U373fast (e), H4 (f) and U343MG (g) showed cytoplasmic positivity. Negative controls using nonspecific lgG remained unlabeled (h). Bar $=100 \mu \mathrm{m}(\mathrm{a}-\mathrm{d})$ and $50 \mu \mathrm{m}(\mathrm{e}-\mathrm{h})$. 
a

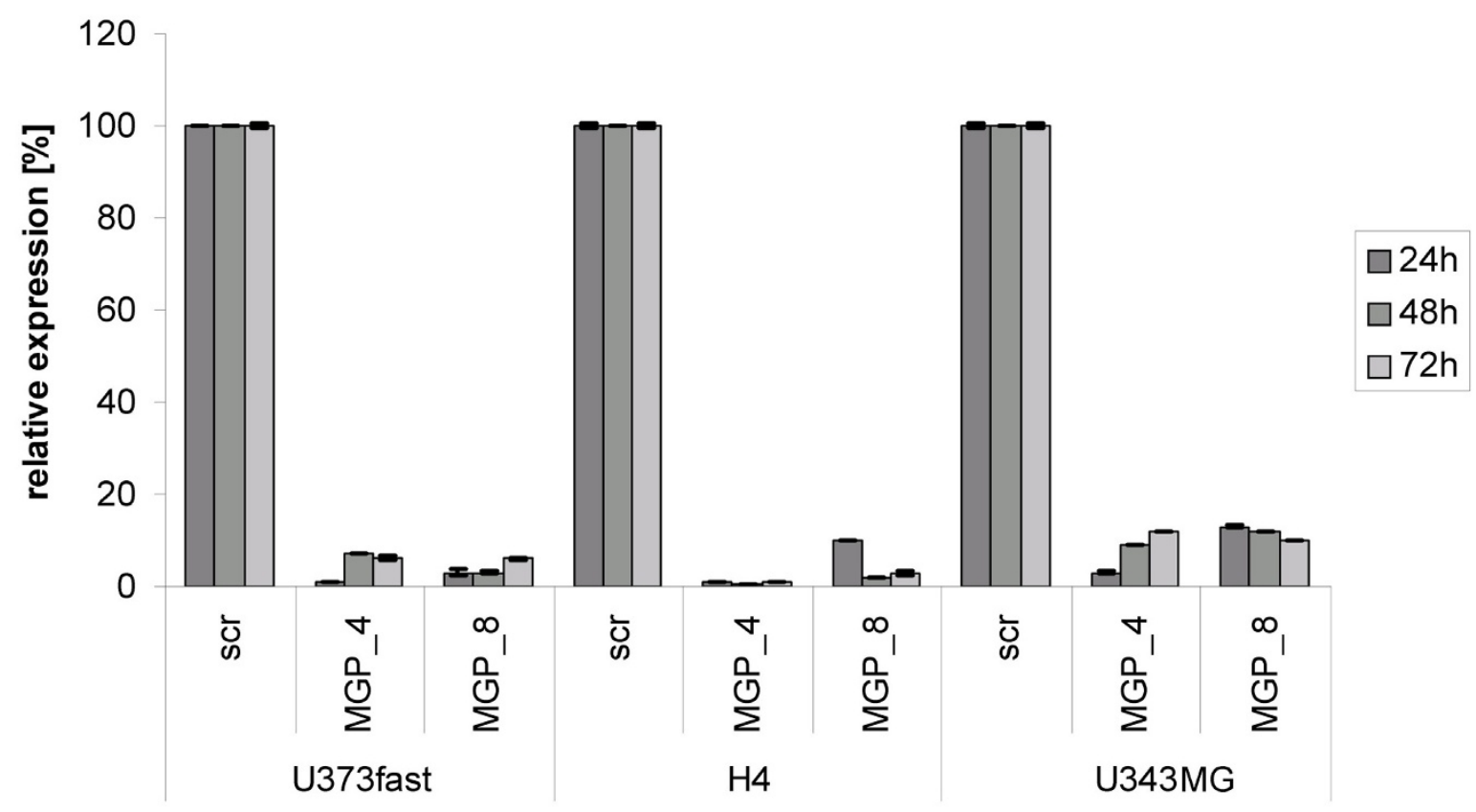

U373fast
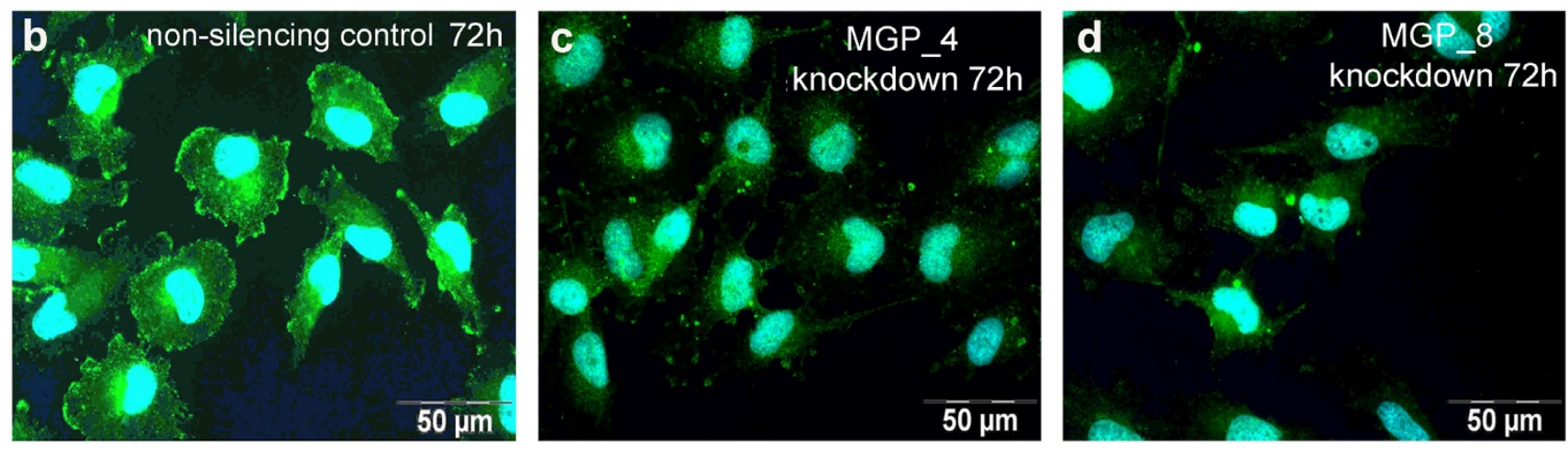

Figure 3

MGP knockdown using siRNA. (a) Transfection of U373fast, $\mathrm{H} 4$ and U343MG cells with two different siRNAs targeting MGP mRNA resulted in decreased MGP expression at mRNA levels at different time points following transfection, as determined by quantitative RT-PCR. MGP mRNA is expressed relative to control transfections using non-silencing siRNA (set at 100\%). b-d: Knockdown verification on protein levels by immunofluorescence staining revealed decreased fluorescence intensities in U373fast cells for both siRNAs $72 \mathrm{~h}$ post-transfection (c, d) compared to control transfected cells (b) (MGP is marked green in the cytoplasm). Similar results were obtained for H4 and U343MG cells. Nuclei were counterstained with Hoechst 33258 (blue). 


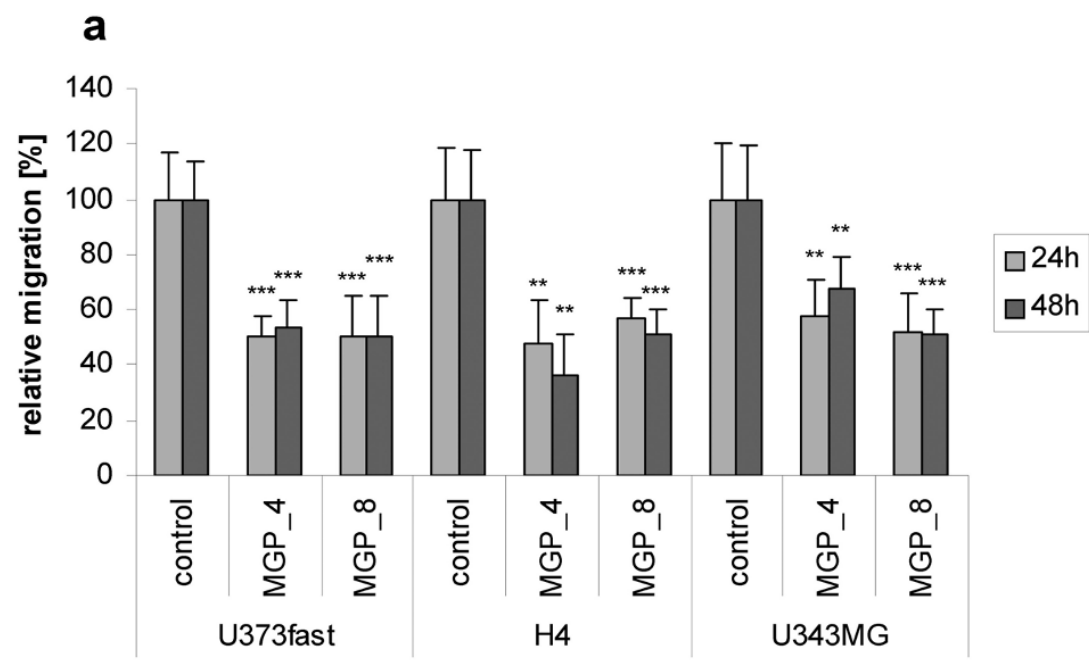

H4
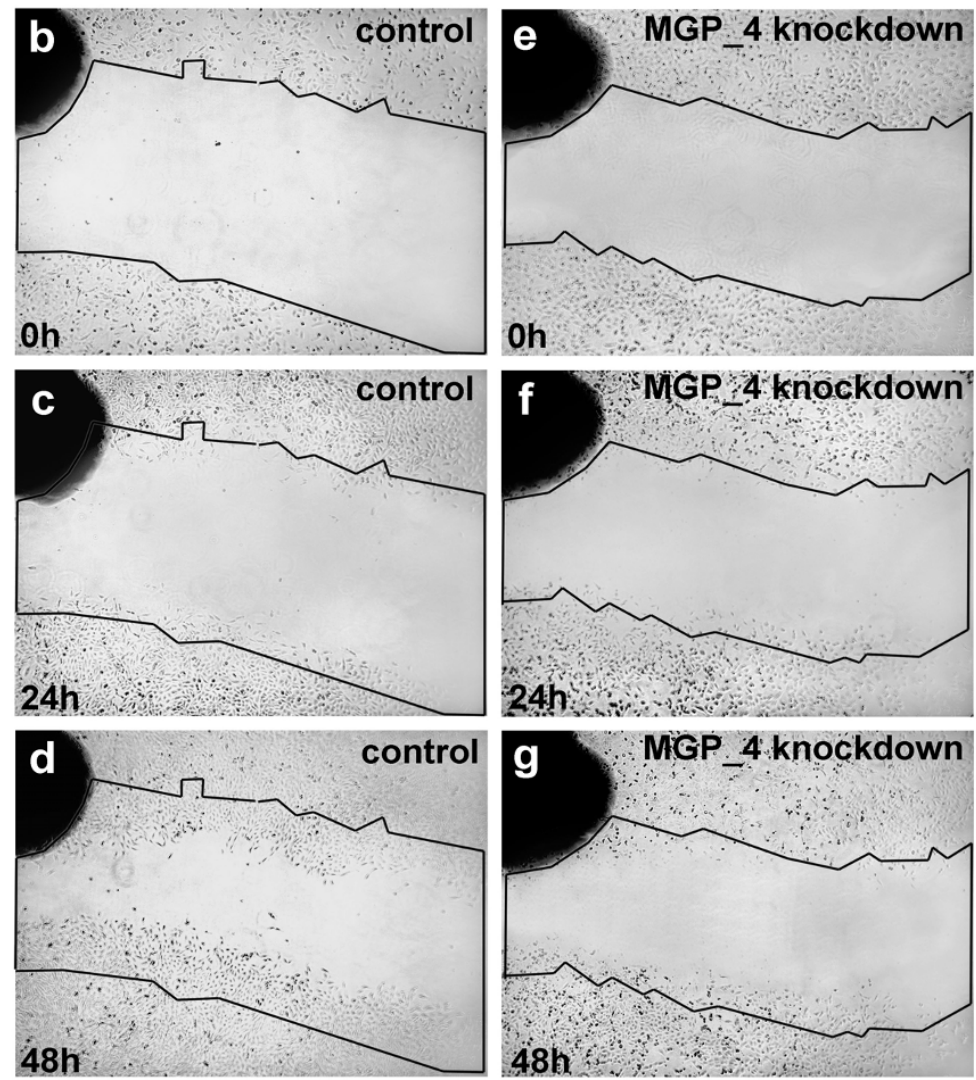

\section{Figure 4}

Migration of glioma cells following MGP knockdown in a wound-healing assay. (a) Quantification of cell migration: U373fast, H4 and U343MG cells with blocked MGP expression exhibited reduced migration as compared to control cells transfected with non-silencing siRNA (set at 100\%). All differences between MGP siRNA and cells transfected with control siRNA are significant $(\mathrm{p}<0.0 \mathrm{I}=* *$ or $\mathrm{p}<0.00 \mathrm{I}=* * *)$. b-g: Representative monolayer wound healing assay using $\mathrm{H} 4$ cells. For better illustration of differences in migration activity, the initial borders of scratch areas are labeled. H4 cells after MGP knockdown (right panels, e, f, g) showed reduced migration into central scratch areas as compared to the control cells, transfected with non-silencing siRNA (left panels, b, c, d). 


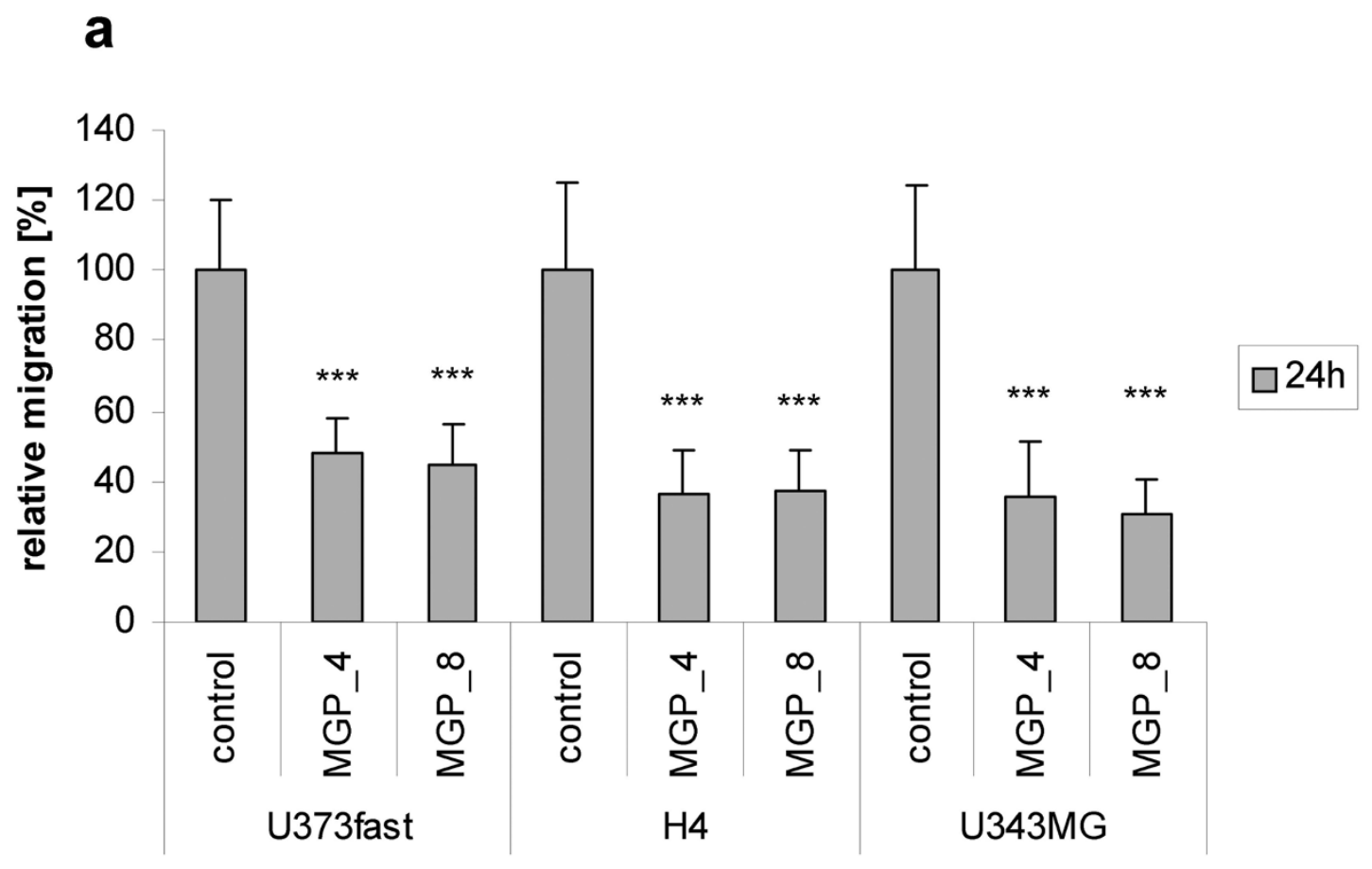

H4
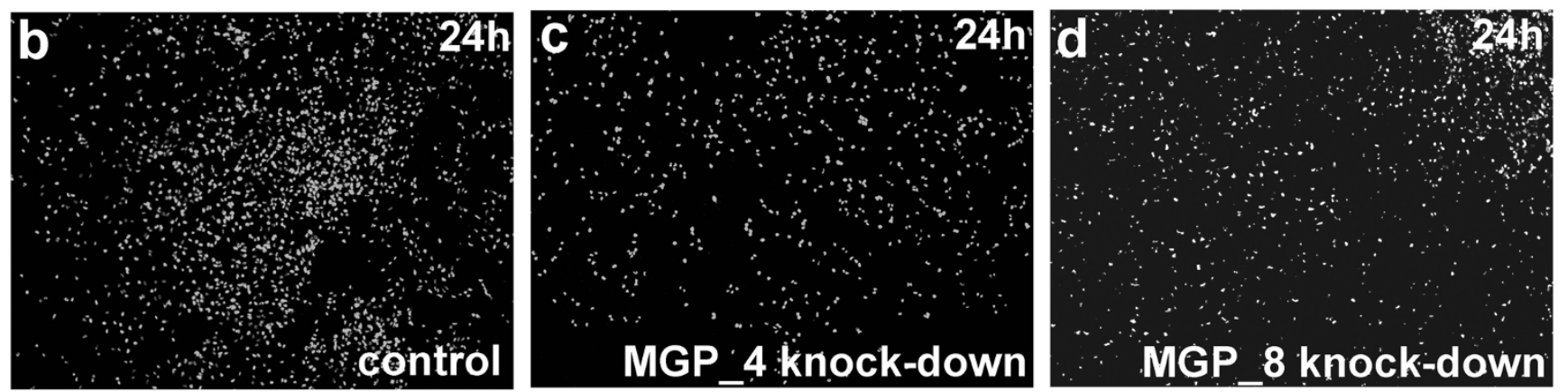

Figure 5

Migration of glioma cells following MGP knockdown using ChemoTX migration chambers. (a) Quantification of cell migration: U373fast, H4 and U343MG cells with reduced MGP expression exhibited reduced migration as compared to control cells transfected with non-silencing siRNA (set at 100\%) $24 \mathrm{~h}$ after seeding in the upper chamber (all differences between siRNA and control transfected cells are significant with $\mathrm{p}<0.00 \mathrm{I}=* * *$ ). b-d: Representative migration chamber assay using $\mathrm{H} 4$ cells. Reduced numbers of $\mathrm{H} 4$ cells were observed on the lower side of the filter following knockdown with MGP specific siRNA (c = siRNA MGP_4, $\mathbf{d}=$ siRNA MGP_8) as compared cells transfected with non-silencing siRNA (b). Nuclei were counterstained with Hoechst 33258.

Glioma cells in vitro and in situ express various ECM components that modulate their microenvironment and promote migration, including collagens, laminins, brevican, tenascin-C and SPARC. These components interact with tumor cells via ECM receptors of the integrin type. Another pair of ECM component/receptor is hyaluronan and CD44 [43]. Several of the components identified in glioma ECMs are permissive substrates enhancing cell migration, but like the interaction of MGP and vitronectin, effects can be modulated by additional ligands or modifications. For example, brevican exposed its promigratory attributes after cleavage by members of the ADAMTS protease family [44] and glioma migration on laminin is stimulated by binding of glycosaminoglycans 
[45]. These findings suggest that it is stimulation of invasion by MGP and other ECM components, which underlies the unfavorable prognosis of glioblastomas with mesenchymal gene expression profile.

\section{Conclusion}

In conclusion, we have demonstrated that MGP is overexpressed in glioma cells, while siRNA mediated knockdown leads to decreased glioma cell migration. Taking into account previous data on negative prognostic effects of MGP overexpression in glioblastomas, our data suggest that upregulation of MGP in concert with other ECMrelated components may result in unfavorable prognosis via increased invasion.

\section{Competing interests}

The authors declare that they have no competing interests.

\section{Authors' contributions}

Sonja Mertsch carried out the molecular studies, participated in functional assays and drafted the manuscript. Leon J. Schurgers carried out the immunohistology staining. Kathrin Weber performed the ELISA. Werner Paulus and Volker Senner conceived of the study, and participated in its design and coordination and helped to draft the manuscript. All authors read and approved the final manuscript.

\section{Acknowledgements}

The authors thank Helene Seifried and Andrea Wagner for excellent technical assistance. This study was supported by Wilhelm Sander Foundation (grant 2005.058.I).

\section{References}

I. Louis DN, Ohgaki H, Wiestler OD, Cavenee WK, Burger PC, Jouvet A, Scheithauer BW, Kleihues P: The 2007 WHO classification of tumours of the central nervous system. Acta Neuropathol 2007, I I 4(2):97-109.

2. Claes A, Idema AJ, Wesseling P: Diffuse glioma growth: a guerilla war. Acta Neuropathol 2007, I I 4(5):443-458.

3. Giese A: Glioma invasion - pattern of dissemination by mechanisms of invasion and surgical intervention, pattern of gene expression and its regulatory control by tumorsuppressor p53 and proto-oncogene ETS-I. Acta Neurochir Suppl 2003, 88: $153-162$.

4. Kleihues P: Glioblastoma. In WHO Classification of Tumours of the Central Nervous System 4th edition. Edited by: David N. Louis HO, Otmar D. Wistler, Webster K. Lyon: WHO; 2007:33-49.

5. McKeever PE: Insights about brain tumors gained through immunohistochemistry and in situ hybridization of nuclear and phenotypic markers. J Histochem Cytochem 1998, 46(5):585-594.

6. Paulus $W$, Huettner C, Tonn JC: Collagens, integrins and the mesenchymal drift in glioblastomas: a comparison of biopsy specimens, spheroid and early monolayer cultures. Int J Cancer 1994, 58(6):84I-846.

7. Freije WA, Castro-Vargas FE, Fang Z, Horvath S, Cloughesy T, Liau LM, Mischel PS, Nelson SF: Gene expression profiling of gliomas strongly predicts survival. Cancer Res 2004, 64(18):6503-65I0.

8. Phillips HS, Kharbanda S, Chen R, Forrest WF, Soriano RH, Wu TD, Misra A, Nigro JM, Colman H, Soroceanu L, et al.: Molecular subclasses of high-grade glioma predict prognosis, delineate a pattern of disease progression, and resemble stages in neurogenesis. Cancer Cell 2006, 9(3): I57-173.
9. Tso CL, Shintaku P, Chen J, Liu Q, Liu J, Chen Z, Yoshimoto K, Mischel PS, Cloughesy TF, Liau LM, et al:: Primary glioblastomas express mesenchymal stem-like properties. Mol Cancer Res 2006, 4(9):607-619.

10. Boom J van den, Wolter M, Kuick R, Misek DE, Youkilis AS, Wechsler DS, Sommer C, Reifenberger G, Hanash SM: Characterization of gene expression profiles associated with glioma progression using oligonucleotide-based microarray analysis and realtime reverse transcription-polymerase chain reaction. $\mathrm{Am} J$ Pathol 2003, 163(3): 1033-1043.

II. Cancela L, Hsieh CL, Francke U, Price PA: Molecular structure, chromosome assignment, and promoter organization of the human matrix Gla protein gene. J Biol Chem 1990, 265(25): I $5040-15048$.

12. Chen L, O'Bryan JP, Smith HS, Liu E: Overexpression of matrix Gla protein mRNA in malignant human breast cells: isolation by differential cDNA hybridization. Oncogene 1990, 5(9): $|39|-\mid 395$.

13. Chen Y, Miller C, Mosher R, Zhao X, Deeds J, Morrissey M, Bryant B, Yang D, Meyer R, Cronin F, et al.: Identification of cervical cancer markers by cDNA and tissue microarrays. Cancer Res 2003, 63(8): 1927-1935.

14. Hough CD, Cho KR, Zonderman AB, Schwartz DR, Morin PJ: Coordinately up-regulated genes in ovarian cancer. Cancer Res 200I, 6 I ( I 0):3869-3876.

15. Levedakou EN, Strohmeyer TG, Effert PJ, Liu ET: Expression of the matrix Gla protein in urogenital malignancies. Int J Cancer 1992, 52(4):534-537.

16. Micke P, Kappert K, Ohshima M, Sundquist $C$, Scheidl S, Lindahl P, Heldin $\mathrm{CH}$, Botling J, Ponten F, Ostman A: In situ identification of genes regulated specifically in fibroblasts of human basal cell carcinoma. J Invest Dermatol 2007, I27(6): 1516-1523.

17. Price PA, Urist MR, Otawara Y: Matrix Gla protein, a new gamma-carboxyglutamic acid-containing protein which is associated with the organic matrix of bone. Biochem Biophys Res Commun 1983, I I 7(3):765-77I.

18. Price PA, Williamson MK: Primary structure of bovine matrix Gla protein, a new vitamin K-dependent bone protein. J Biol Chem 1985, 260(28): | 497|-|4975.

19. Luo G, Ducy P, McKee MD, Pinero GJ, Loyer E, Behringer RR, Karsenty G: Spontaneous calcification of arteries and cartilage in mice lacking matrix GLA protein. Nature 1997, 386(6620):78-8I.

20. Munroe PB, Olgunturk RO, Fryns JP, Van Maldergem L, Ziereisen F, Yuksel B, Gardiner RM, Chung E: Mutations in the gene encoding the human matrix Gla protein cause Keutel syndrome. Nat Genet 1999, 21(1): 142-144.

21. Tatenhorst L, Senner V, Puttmann S, Paulus W: Regulators of Gprotein signaling 3 and 4 (RGS3, RGS4) are associated with glioma cell motility. J Neuropathol Exp Neurol 2004, 63(3):210-222.

22. Schurgers LJ, Teunissen KJ, Knapen $M H$, Geusens $P$, Heijde $D$ van der, Kwaijtaal M, van Diest R, Ketteler M, Vermeer C: Characteristics and performance of an immunosorbent assay for human matrix Gla-protein. Clin Chim Acta 2005, 35 I (I-2): | 3 |- I 38.

23. Schurgers LJ, Teunissen KJ, Knapen $M H$, Kwaijtaal M, van Diest $R$, Appels A, Reutelingsperger CP, Cleutjens JP, Vermeer C: Novel conformation-specific antibodies against matrix gamma-carboxyglutamic acid (Gla) protein: undercarboxylated matrix Gla protein as marker for vascular calcification. Arterioscler Thromb Vasc Biol 2005, 25(8): 1629-1633.

24. Goritz C, Thiebaut R, Tessier LH, Nieweg K, Moehle C, Buard I, Dupont JL, Schurgers LJ, Schmitz G, Pfrieger FW: Glia-induced neuronal differentiation by transcriptional regulation. Glia 2007 , 55(II): I I08-II 22

25. Murshed M, Schinke T, McKee MD, Karsenty G: Extracellular matrix mineralization is regulated locally; different roles of two gla-containing proteins. J Cell Biol 2004, 165(5):625-630.

26. Price PA, Faus SA, Williamson MK: Warfarin causes rapid calcification of the elastic lamellae in rat arteries and heart valves. Arterioscler Thromb Vasc Biol 1998, 18(9): I400-I 407.

27. Schurgers LJ, Aebert $\mathrm{H}$, Vermeer C, Bultmann B, Janzen J: Oral anticoagulant treatment: friend or foe in cardiovascular disease? Blood 2004, 104(10):3231-3232.

28. Bostrom K, Zebboudj AF, Yao Y, Lin TS, Torres A: Matrix GLA protein stimulates VEGF expression through increased 
transforming growth factor-betal activity in endothelial cells. J Biol Chem 2004, 279(5 I):52904-529/3.

29. Fan C, Sheu D, Fan H, Hsu K, Allen Chang C, Chan E: Down-regulation of matrix Gla protein messenger RNA in human colorectal adenocarcinomas. Cancer Lett 200I, 165(I):63-69.

30. Wozney JM, Rosen V, Celeste AJ, Mitsock LM, Whitters MJ, Kriz RW, Hewick RM, Wang EA: Novel regulators of bone formation: molecular clones and activities. Science 1988, 242(4885): I528-I534.

31. Nishimoto SK, Nishimoto M: Matrix Gla protein C-terminal region binds to vitronectin. Co-localization suggests binding occurs during tissue development. Matrix Biol 2005, 24(5):353-36I.

32. Zebboudj AF, Imura M, Bostrom K: Matrix GLA protein, a regulatory protein for bone morphogenetic protein-2. J Biol Chem 2002, 277(6):4388-4394.

33. Lee J, Son MJ, Woolard K, Donin NM, Li A, Cheng CH, Kotliarova S, Kotliarov Y, Walling J, Ahn S, et al.: Epigenetic-mediated dysfunction of the bone morphogenetic protein pathway inhibits differentiation of glioblastoma-initiating cells. Cancer Cell 2008, I3(I):69-80.

34. Piccirillo SG, Reynolds BA, Zanetti N, Lamorte G, Binda E, Broggi G, Brem $\mathrm{H}$, Olivi A, Dimeco $F$, Vescovi AL: Bone morphogenetic proteins inhibit the tumorigenic potential of human brain tumour-initiating cells. Nature 2006, 444(7 I 20):76I-765.

35. Canoll P, Goldman JE: The interface between glial progenitors and gliomas. Acta Neuropathol 2008, I I 6(5):465-77.

36. Dufourcq P, Louis H, Moreau C, Daret D, Boisseau MR, Lamaziere $J M$, Bonnet J: Vitronectin expression and interaction with receptors in smooth muscle cells from human atheromatous plaque. Arterioscler Thromb Vasc Biol I998, I8(2): 168-176.

37. Jang YC, Tsou R, Gibran NS, Isik FF: Vitronectin deficiency is associated with increased wound fibrinolysis and decreased microvascular angiogenesis in mice. Surgery 2000 127(6):696-704.

38. Podor TJ, Peterson CB, Lawrence DA, Stefansson S, Shaughnessy SG, Foulon DM, Butcher M, Weitz Jl: Type I plasminogen activator inhibitor binds to fibrin via vitronectin. J Biol Chem 2000, 275(26): 19788-19794.

39. Zheng X, Saunders TL, Camper SA, Samuelson LC, Ginsburg D: Vitronectin is not essential for normal mammalian development and fertility. Proc Natl Acad Sci USA 1995 92(26): 12426-12430.

40. Gladson CL, Cheresh DA: Glioblastoma expression of vitronectin and the alpha v beta 3 integrin. Adhesion mechanism for transformed glial cells. J Clin Invest 1991, 88(6): 1924-1932.

41. Uhm JH, Dooley NP, Kyritsis AP, Rao JS, Gladson CL: Vitronectin, a glioma-derived extracellular matrix protein, protects tumor cells from apoptotic death. Clin Cancer Res 1999, 5(6): $1587-1594$

42. Gladson CL, Wilcox JN, Sanders L, Gillespie GY, Cheresh DA: Cerebral microenvironment influences expression of the vitronectin gene in astrocytic tumors. J Cell Sci 1995, I08(Pt 3): $947-956$.

43. Bellail AC, Hunter SB, Brat DJ, Tan C, Van Meir EG: Microregional extracellular matrix heterogeneity in brain modulates glioma cell invasion. Int J Biochem Cell Biol 2004, 36(6): I046-1069.

44. Hu B, Kong LL, Matthews RT, Viapiano MS: The proteoglycan brevican binds to fibronectin after proteolytic cleavage and promotes glioma cell motility. J Biol Chem 2008, 283(36):24848-24859.

45. Aguiar CB, Lobao-Soares B, Alvarez-Silva M, Trentin AG: Glycosaminoglycans modulate $\mathrm{C} 6$ glioma cell adhesion to extracellular matrix components and alter cell proliferation and cell migration. BMC Cell Biol 2005, 6:3I.

\section{Pre-publication history}

The pre-publication history for this paper can be accessed here:

\section{http://www.biomedcentral.com/1471-2407/9/302/pre} pub
Publish with Bio Med Central and every scientist can read your work free of charge

"BioMed Central will be the most significant development for disseminating the results of biomedical research in our lifetime. "

Sir Paul Nurse, Cancer Research UK

Your research papers will be:

- available free of charge to the entire biomedical community

- peer reviewed and published immediately upon acceptance

- cited in PubMed and archived on PubMed Central

- yours - you keep the copyright

Submit your manuscript here:

http://www.biomedcentral.com/info/publishing_adv.asp
BioMedcentral 